\title{
Pemberian Konseling tentang penyakit Acute Nasopharyngitis (common cold) di Klinik Goa Ria, Makassar
}

\author{
Ferna Indrayani \\ STIKES Nani Hasanuddin Makassar, Jl. Perintis Kemerdekaan VIII, No. 24, Kota Makassar, Indonesia, 90245) \\ *e-mail :ferna@stikesnh.ac.id
}

\begin{abstract}
Abstrak
Program kegiatan pengabdian kepada masyarakat yaitu Pemberian Konseling tentang penyakit Acute Nasopharyngitis (Common cold) di Klinik Goa Ria, Makassar. Pemberian konseling merupakan salah satu program yang dirancang untuk diterapkan untuk meningkatkan kesehatan,pengetahun dan kualitas hidup masyarakat.. Secara umum tujuan kegiatan ini yaitu mendorong terjadinya proses perubahan perilaku ke arah yang positif, peningkatan pengetahuan, sikap dan praktik masyarakat secara wajar sehingga masyarakat melaksanakannya secara mantap. Metode yang digunakan dalam pencapaian tujuan adalah metode pemberian edukasi,komunikasi dan informasi tentang terapi Acute Nasopharyngitis (common cold). Hasil dari kegiatan PKM diharapkan pasien yang mengidap penyakit Acute Nasopharyngitis (common cold) menjaga kesehatan.
\end{abstract}

Kata Kunci : Konseling, Acute Nasopharyngitis (common cold).

\section{Pendahuluan}

Infeksi saluran napas atas merupakan penyakit yang paling banyak terjadi pada masyarakat. Infeksi saluran napas atas meliputi rhinitis, sinusitis, faringitis, laringitis, epiglotitis, tonsilitis, dan otitis. Infeksi saluran napas atas bila tidak diatasi dengan baik dapat berkembang menyebabkan infeksi saluran napas bawah. Infeksi saluran pernapasan atas perlu penanganan dengan baik karena dampak komplikasinya yang membahayakan adalah otitis, sinusitis, dan faringitis (Depkes RI, 2005). Secara umum penyebab dari infeksi saluran napas atas adalah berbagai mikroorganisme, namun yang terbanyak akibat infeksi virus dan bakteri. Infeksi saluran napas atas dapat terjadi sepanjang tahun, meskipun beberapa infeksi lebih mudah terjadi pada musim hujan, salah satu penyakit infeksi pasa saluran pernafasan adalah common cold (Depkes RI, 2005). Penyakit Common cold merupakan penyakit yang disebabkan oleh virus dan faktor pendukung lainnya. Tingkat kejadian penyakit ini dari tahun ketahun terjadi peningkatan. Common Cold adalah infeksi primer di nasofaring dan hidung yang sering mengeluarkan cairan, penyakit ini banyak dijumpai pada bayi dan anak. Dibedakan istilah nasofaring akut untuk anak dan common cold untuk orang dewasa oleh karena manifestasi klinis penyakit ini pada orang dewasa dan anak berlainan. Pada anak infeksi lebih luas, mencakup daerah sinus paranasal, telinga tengah disamping nasofaring, disertai demam yang tinggi. Pada orang dewasa infeksi mencakup daerah terbatas dan biasanya tidak disertai demam yang tinggi (Ngastiyah, $1997: 12$ ).

Pada dasarnya penyakit batuk dan pilek pada Bayi maupun Balita dapat disebabkan oleh banyak faktor. Sebagian besar penyebabnya adalah virus. Selain virus batuk dan pilek serta demam tidak saja dipengaruhi oleh virus tetapi dapat juga disebabkan oleh bakteri (Danarti, 2010 : 2-3). Bagi kebanyakan orang, flu dianggap hal yang biasa dan akan sembuh dengan sendirinya dalam 1 atau 2 minggu. Namun bagi sebagian orang flu dapat membuat mereka sangat menderita, mereka yang dimaksud adalah bayi dan anak usia dibawah lima tahun (Aden R, 2010: 2 dan 22). Pada Bayi, Balita dan Anak, infeksi saluran nafas yaitu Common cold sangat berbahaya karena dapat menggangu makan dan kadang-kadang menyebabkan infeksi saluran nafas bawah yang lebih akut apabila tidak ada perhatian khusus dari orang tua maupun peran perawat di masyarakat serta menentukan apakah diperlukan intervensi medis (Gould, 2003 : 219220).

Pemahaman terhadap permasalahan kesehatan masyarakat terutama pada penyakit yang dialami oleh masyarakat dikarenakan tenaga kesehatan tidak memiliki dasar pemahaman yang kuat sehingga konsep penyakit dan dan masalah kesehatan antar tenaga kesehatan dan masyarakat gagal dalam meningkatkan derajat kualitas hidup masyarakat. Berdasarkan hal tersebut maka dilaksanakan kegiatan pengabdian kepada masyarakat dalam bentuk Pemberian konseling . Konseling merupakan salah satu cara yang dapat dilakukan untuk meningkatkan pengetahuan atau informasi bagi masyarakat (Mashuda, 2011). Permendiknas no.27 tahun 2008 mengenai standar kualifikasi dan kompetensi konselor. Terkait dengan hal tersebut maka dalam pelaksanaannya konselor dituntut untuk memiliki keterampilan yang profesional terutama dalam melakukan layanan konseling. Kompetensi yang harus dibentuk agar konselor dapat menjalankan konseling dengan profesional adalah kompetensi mengelola pikiran atau lebih dikenal dengan mindskills (Jones, 2005). 
Adapun tujuan dari kegiatan ini yaitu untuk mengetahui pemahaman pasien dalam menggunakan obat yang diberikan oleh dokter serta memastikan agar pasien menggunakan obat secara benar. Manfaat dalam kegiatan yakni dapat membantu pasien agar tidak terjadi kesalahan dalam penggunaan obat serta menjamin kerasionalan pengobatan.

Klinik goa ria adalah fasilitas kesehatan yang terletak di wilayah sudiang Kecamatan biringkanaya kelurahan PAI. yang melayani pasien umum dan pasien bpjs. Dimana klinik tersebut terdiri dari poli umum, poli gigi dan apotek. Klinik goa ria memiliki jumlah pasien bpjs kurang lebih dari 9.000 pasien. Masyarakat di daerah sudiang senang berobat di klinik goa ria dikarenakan klinik tersebut buka setiap hari kecuali pada hari raya. Dari data awal pada saat survei lokasi penyakit yang paling banyak di derita oleh pasien disana adalah penyakit common cold. Mengingat bahwa penyakit common cold yang paling banyak terjadi penyalah gunaan obat seperti penggunaan antibiotik, maka perlu dilakukan pemberian konseling tentang cara penggunaan obat yang benar, pola hidup sehat, terapi non farmakologi melalui perbanyak waktu istirahat sehingga pasien di klinik goa ria tidak terjadi resistensi antibiotic.

\section{Metode Pelaksanaan}

\section{A. Pengenalan dan Persiapan}

Tahapan awal yang dilakukan dalam kegiatan ini yakni melakukan survei lokasi dan berdiskusi dengan pemilik klinik goa ria dengan membahas tentang tujuan dari program yang akan dilakukan di klinik tersebut dengan mencatat data penyakit yang paling banyak di derita oleh pasien di klinik. Setelah mendapatkan ijin dari pemilik klinik, kemudian mempersiapkan surat tugas dari Institusi.

B. Mekanisme Pelaksanaan Pengabdian Masyarakat

Metode yang digunakan pada kegiatan ini adalah metode konseling, dengan menggunakan tekhnik wawancara meliputi Attending, Opening, Acceptance, Restatement, Reflection of Feeling, Paraphrashing, Clarification, Structuring, Leading, Silence, Reassurance, Rejection, Advice,

Confrontation, Interpretation, Summary dan Termination. Dengan tekhnik konseling maka akan tercipta komunikasi yang efektif dan efisien.

\section{Hasil}

A. Karakteristik Peserta

Dari hasil kegiatan yang telah dilakukan, maka dapat dilihat dari tabel dibawah ini;

Tabel 1. Distribusi frekuensi karateristik peserta pengabdian masyarakat

\begin{tabular}{|c|c|c|c|}
\hline No & Karakteristik Responden & $\mathrm{n}$ & $\%$ \\
\hline & Jenis Kelamin & & \\
& Perempuan & 9 & 75 \\
& Laki-laki & 3 & 25 \\
\hline \multirow{4}{*}{2} & Tingkat Pendidikan & & \\
& SD & 2 & 16,7 \\
& SMP & 0 & 0 \\
& SMA & 3 & 25 \\
& PT & 7 & 58,3 \\
\hline \multirow{4}{*}{3} & Pekerjaan & 0 & 0 \\
& PNS & 9 & 75 \\
& Wiraswasta & 2 & 16.7 \\
& IRT & 1 & 8,3 \\
\hline \multicolumn{2}{|c}{} \\
\end{tabular}

Tabel 1. Menunjukkan bahwa distribusi peserta kegiatan pengabdian kepada masyarakat ini lebih dominan berdasarkan jenis kelamin yaitu perempuan sebesar 75\%, tingkat pendidikan terakhir yaitu Perguruan tinggi sebesar $58,3 \%$, dan pekerjaan sebagai Wiraswasta sebesar $75 \%$.

B. Respon Peserta

Pada awal kegiatan semua pasien diharapkan untuk mendaftar diruang administrasi kemudian duduk di ruang tunggu untuk menunggu panggilan masuk keruangan dokter. Setelah itu pasien keluar dengan membawa resep dan mulai duduk di ruang konsultasi dikarenakan pasien yang ingin mengetahui tentang penggunaan obat yang benar. Hal ini terlihat dari antusias pasien yang menunggu antrian untuk berkonsultasi walaupun bukan hanya penyakit common cold saja. Sebelum dilakukan konseling agar dapat menilai pemahaman pasien tentang penggunaan obat maka terlebih dahulu saya mengajukan three prime questions a. Apa yang disampaikan dokter tentang Obat Anda? b. Apa yang dijelaskan oleh dokter tentang cara pemakaian Obat Anda? c. Apa yang dijelaskan oleh dokter tentang hasil yang diharapkan setelah Anda menerima terapi Obat tersebut? Dengan memberikan kesempatan kepada pasien untuk mengajukan pertanyaan terkait penggunaan obat. Oleh karena itu, kegiatan pengabdian kepada masyarakat 
dengan metode konseling sangat diperlukan bagi pasien atau masyarakat yang membutuhkan informasi obat yang benar.

C. Luaran Kegiatan

Gambar 1. Dokumentasi kegiatan pemberian konseling

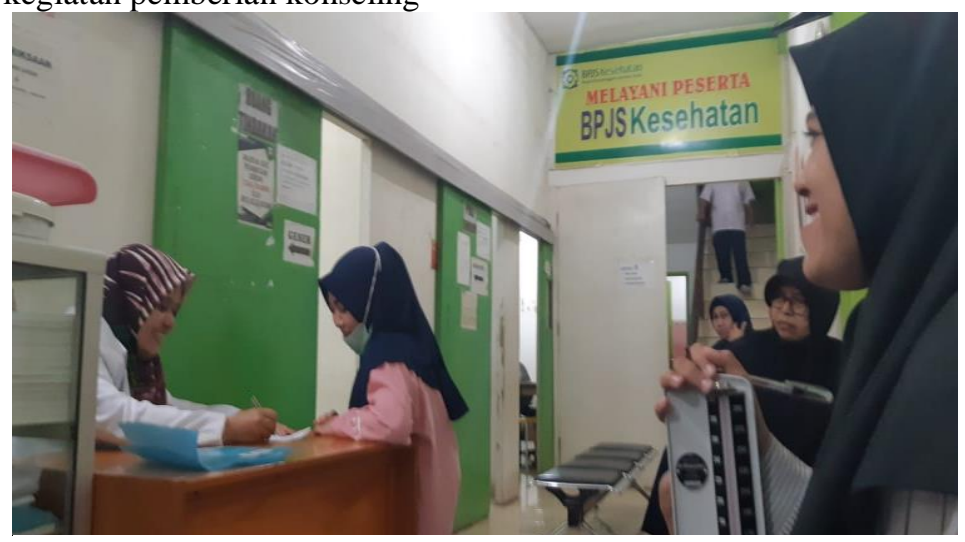

Hasil pengabdian kepada masyarakat melalui metode konseling menunjukkan bahwa adanya pasien lebih mengetahui dan memahami penggunaan obat yang benar yang dapat dilihat ketika pasien memberikan respon balik ketika ditanya sebelumnya setiap menderita common cold selalu mengkonsumsi obat antibiotic yang dimana diketahui bahwa penyakit common cold disebabkan oleh virus bukan bakteri. Tujuan dari untuk mengetahui pemahaman pasien dalam menggunakan obat yang diberikan oleh dokter serta memastikan agar pasien menggunakan obat secara benar. Manfaat dalam kegiatan yakni dapat membantu pasien agar tidak terjadi kesalahan dalam penggunaan obat serta menjamin kerasionalan pengobatan.

Pasien Acute Nasopharyngitis (Common cold) kurang memahami tentang penggunaan obat yag benar untuk penyakit tersebut, dikarenakan kebanyakan dari pasien tersebut membeli obat dengan menggunakan kombinasi obat antibiotik. Tingginya prevalensi infeksi saluran pernapasan atas (ISPA) serta dampak yang ditimbulkannya membawa akibat pada tingginya konsumsi obat bebas (seperti anti influenza, obat batuk, multivitamin) dan antibiotika. Dalam kenyataan antibiotika banyak diresepkan untuk mengatasi infeksi ini. Peresepan antibiotika yang berlebihan tersebut terdapat pada infeksi saluran napas khususnya infeksi saluran napas atas akut, meskipun sebagian besar penyebab dari penyakit ini adalah virus. Salah satu penyebabnya adalah ekspektasi yang berlebihan para klinisi terhadap antibiotika terutama untuk mencegah infeksi sekunder yang disebabkan oleh bakteri, yang sebetulnya tidak bisa dicegah. Dampak dari semua ini adalah meningkatnya resistensi bakteri maupun peningkatan efek samping yang tidak diinginkan(Reese Richard E, et al. 2000)

Salah satu upaya kesehatan melalui pelayanan kefarmasian adalah memberikan konseling. Menurut Permenkes no 73 tahun 2016 menjelaskan bahwa pelayanan farmasi klinik meliputi: a. pengkajian Resep; b. dispensing; c. Pelayanan Informasi Obat (PIO); d. konseling; e. Pelayanan Kefarmasian di rumah (home pharmacy care); f. Pemantauan Terapi Obat (PTO); dan g. Monitoring Efek Samping Obat (MESO). Konseling merupakan proses interaktif antara Apoteker dengan pasien/keluarga untuk meningkatkan pengetahuan, pemahaman, kesadaran dan kepatuhan sehingga terjadi perubahan perilaku dalam penggunaan Obat dan menyelesaikan masalah yang dihadapi pasien. Untuk mengawali konseling, Apoteker menggunakan three prime questions. Apabila tingkat kepatuhan pasien dinilai rendah, perlu dilanjutkan dengan metode Health Belief Model. Apoteker harus melakukan verifikasi bahwa pasien atau keluarga pasien sudah memahami Obat yang digunakan.

\section{Kesimpulan}

Dari hasil kegiatan Pengabdian Kepada Masyarakat dapat disimpulkan berdasarkan kelebihan dari kegiatan ini yaitu Pasien yang datang ke klinik goa ria mampu menerima informasi terkait tentang penyakit Acute Nasopharyngitis (Common cold) dan terjadinya umpan balik dari pasien terkait pengobatan yang digunakan. Serta kekurangan dari kegiatan ini adalah keterbatasan waktu dalam memberikan infomasi dan edukasi terkait penggunaan obat.

\section{Rekomendasi}

Diharapkan melakukan penyuluhan tentang pemanfaatan obat-obat tradisional. 


\section{Ucapan Terima Kasih}

Terima kasih kepada ketua LP3M STIKES Nani Hasanuddin Makassar yang telah memberikan surat rekomendasi serta dukungan yang penuh untuk melakukan salah satu kegiatan tridharma perguruan tinggi dan pemilik klinik goa ria serta tenaga kesehatan yang telah membantu dalam kelancaran dan tercapainya tujuan kegiatan tersebut dan kepada para pasien yang telah menerima dengan baik informasi obat yang disampaikan oleh konselor .

\section{Daftar Pustaka}

Aden. 2010. Seputar Penyakit dan Gangguan Lain Pada Anak. Yogyakarta: Hanggar Kreator.

Departemen Kesehatan RI, 2009. Sistem Kesehatan Nasional. Jakarta.

Depkes RI, 2005, Pharmacetical Care Untuk Penyakit Saluran Pernafasan, Departemen Kesehatan RI, Jakarta.Dinkes Prov. Sulbar, 2017. Pemantauan Status Gizi 2017.

Danarti, D., 2010. Menjadi Orang Tua Pintar Agar Anak Sukses. Yogyakarta : Smart Parenting

Gould. 2013. Mikrobiologi Terapan untuk Kesehatan, cetakan pertama, Jakarta, penerbit buku kedokteran EGC.

https://petalokasi.org/Kabupaten-Bone/Apotik-Goa-Ria-Farma-190412/

Jones, R. N. 2005. Practical Counselling and Helping Skills. London: Sage Publications

Kementerian Kesehatan Republik Indonesia, 2011. Pedoman Interpretasi Data Klinik. Jakarta

Lacy, C,F.,dkk., 2010. Drug Information Handbook, 18th editionlexi_comp, USA.

Mashuda, A., 2011, Pedoman Cara Pelayanan Kefarmasian yang Baik (CPFB), Kementerian Kesehatan RI, Jakarta.

Mulawarman, 2017, Buku Ajar Pengantar Keterampilan Dasar Konseling bagi Konselor Pendidikan, Universitas Negeri Semarang, Semarang

Ngastiyah. (1997). Perawatan Kesehatan Anak. UI; Jakarta

Peraturan Pemerintah., 2014. Penyelenggaraan Pendidikan Tinggi dan Pengelolaan Perguruan Tinggi. Republik Indonesia, Jakarta

Permenkes no 73 tahun 2016. Standar Pelayanan Kefarmasian di Apotek

Reese Richard E, et al. Handbook of Antibiotics.3rd ed. Lippincott Williams\&Wilkins, Philadelphia 2000: 3-5. 